\title{
Effective control of varroatosis using powdered thymol
}

\author{
F Chiesa
}

with the technical collaboration of M D'Agaro

Istituto di Difesa delle Piante, Università degli Studi, Piazzale M Kolbe 4, 33100 Udine, Italy

(Received 17 July 1990; accepted 20 January 1991)

Summary - in order to provide a consistent control of varroatosis without harmful effects such as the occurrence of toxic residues in the hive products, treatment with powdered thymol was tested during a 2-yr research trial. Treatment consisted of 4 identical applications carried out at 2-day intervais on honeybee colonies with little or no brood. In all hives during both years, mite populations were drastically reduced as a consequence of treatment ( $96.77 \%$ on average) indicating that thymol is worth further study. The rate of mite fall was highest in the hours immediately following each application and was positively influenced by outdoor temperatures. The addition of confectioner's sugar to thymol seemed to enhance both effectiveness and rate of mite fall though significant effects were not achieved. Modified Gary's traps installed on treated and untreated colonies showed that bee mortality was generally affected by treatment.

Apls mellfera / varroatosis / chemlcal control / thymol

\section{INTRODUCTION}

As the reproductive behaviour of Varroa jacobsoni Oud is still imperfectly understood and natural enemies or resistant honeybee strains are as yet unknown, acaricide treatments are the most effective and expedite way to control the disease. Results so far obtained with chemical substances should not impede further attempts to find a solution, as tolerability by bees and toxic residues in hive products may constitute serious drawbacks in this control strategy.

Previous research on acarine disease indicates that pesticides can be adequately replaced by organic compounds found in nature, such as essential oils (Vecchi and Giordani, 1968; Leporati and Giorda- ni, 1982; Wilson et al, 1988; Hoppe and Ritter, 1989). These oils are synthetized by several plant species for a number of purposes including attracting insects for cross-pollination and preventing severe damage by insects, grazing animals and fungi (Saleh, 1986). Interestingly enough, essential oils are normal constituents of some honeys and are widely used as flavouring agents in food and drugs.

Without doubt, 5-methyl-2(1-methylethyl) phenol, usually named thymol, is one of the most versatile components of essential oils. At given concentrations it has antiseptic and antimycotic properties (Windholz, 1983; Galoppini, 1985) and is successfully employed in pharmaceutical chemistry (Cooperativa Farmaceutica Milano, 1980; Reynolds, 1982). In addition, it 
is used in the food and cosmetic industry (Fenaroli, 1963).

In beehives thymol has been proposed for the treatment of Ascosphaera apis (Eble and Weide, 1961; Colin et al, 1989), the etiological agent of chalk brood, and possibly other organisms which cause diseases (Kostecki, 1976; Grobov et al, 1981). However, varroatosis is by far the disease on which the most experiments have been carried out using thymol (Sidorov et al, 1977; Smirnov, 1978; Mikityuk et al, 1979; Grobov et al, 1981; Mautz, 1982; Kambourov et al, 1983; Mikityuk, 1983; Mladan et al, 1985). In this regard, it is worth noting that the large spectrum of activity could be helpful in preventing the development of those microorganisms which parallel infestation of varroatosis or arise as a consequence of the weakening of bee colonies by varroatosis (Grobov et al, 1981).

The formulation of the product appeared to be one of the major factors affecting its effectiveness. Marchetti and Barbattini (1984) achieved inconsistent results when treating honeybee colonies 4 times with a 15-g dose of thymol crystals per colony, as indeed occurred in other experiments (Mikityuk, 1983). When crystals were ground to powder, percent effectiveness increased to levels shown by the best acaricides produced only via chemical synthesis (Mladan et al, 1985).

To provide additional data on treatment with powdered thymol a 2-yr research trial was carried out. In particular, the objectives of this study were to ascertain the following: 1), the effectiveness of the product under local conditions of bee strain, temperature and type of hive; 2 ), the mode of action of the product against time; 3 ), verify the extent of tolerability by bees; and 4), the effect of outdoor temperatures, product composition and colony strength on effectiveness of control and bee mortality.

\section{MATERIALS AND METHODS}

\section{Testing year 1987}

Treatment was carried out at Moruzzo, northeast Italy, on 10 honeybee colonies derived from free-flying crosses and recrosses between Apis mellifera ligustica Spinola and $A m$ carnica Pollmann; colonies were reared in Dadat-Blatt type hives with 10 combs and at the time of treatment had little or no brood.

Thymol crystals (synthesised by Janousek, Fratelli, Italy, with a thymol content of nearly $99 \%$ ) were powdered in a homogenizer and, using a tea-strainer, sprinkled onto the top bars of the combs occupied by bees. Doses varied according to the colonies' strength which was estimated $2 \mathrm{~d}$ before treatment as described previously (Marchetti, 1985); a 0.5-g dose of thymol was applied to each comb completely filled with bees. Treatment consisted of 4 identical applications carried out at 2-d intervals beginning on October 28 at $3.30 \mathrm{pm}$.

Dead mites were collected on plastic trays smeared with vaseline placed at the bottom of all the hives being tested (contact of bees prevented by a $2.5-\mathrm{mm}$ mesh). Following the first and last application, the inserts were swiftly substituted to provide information on the relationship between time and rate of mite fall. After the first application, replacements were made after $3,6,9,12,15,18,21,24,27,30,42$ and $48 \mathrm{~h}$, whereas for the fourth application the inserts were replaced at 24-h intervals for 20 consecutive $d$.

To determine the effectiveness of thymol, 2 treatments with Perizin (Bayer) and 2 with Taktic (Fbc) were carried out. The former product was applied on November 26 and 30 following the manufacturer's instructions, the latter on December 2 and 4 using an aerosol formulation obtained by using the atomizer Phagogene S Microdiffuseur with a temperature at the exit of $37^{\circ} \mathrm{C}$. The concentration of Amitraz in the emulsion was $2 \mathrm{ml} / /$ and $90 \mathrm{~s}$ were necessary to treat one colony. Judging from former results relative to these chemicals (Marchetti and Barbattini, 1984; Marchetti and D'Agaro, 1986), the number of mites still surviving should have been negligible. During the trial, outdoor temperatures and relative humidities were recorded with a 1750/1 Salmoiraghi thermohygrometer. 


\section{Testing year 1988}

Colonies used the previous year were treated following an almost identical procedure; the main differences were that: 1), in 5 randomly chosen hives a mixture of thymol and confectioner's sugar (TCS) $(1: 1 \mathrm{w} / \mathrm{w})$ was applied instead of thymol alone $(T) ; 2$ ), one $\mathrm{g}$ of thymol was applied to each colony independently of its strength; 3), just before treatment, a sheet of filter paper was placed in front of the hive entrance to prevent bees from leaving. The treatment began on November 7 at $4.30 \mathrm{pm}$. At Moruzzo, outdoor temperatures and relative humidities were recorded using the same instrument as the previous year.

A replication of the test was made in a milder climate (Udine) on colonies of the same strain. The 20 hives available were randomly selected for treatment with T (7), TCS (6), or left untreated (7). Due to technical reasons, treatment was postponed by exactly $1 \mathrm{~d}$ in respect to the other location. At both locations the effectiveness of $T$ and TCS was determined by means of 2 treatments with Taktic carried out, as in the previous year, on December 7 and 13. In Udine an HI 70601 Hanna Instruments thermohygrometer was used to record meteorological data; the measurements were taken automatically at intervals of $1 \mathrm{~min}$ and every $\mathrm{h}$ the average was recorded (Metrosonics data logger dL 714).

All hives were provided with modified Gary's traps (Gary, 1960; Marchetti et al, 1987) which were installed 1 wk before treatment; the number of dead bees was counted daily until the end of the trial.

\section{Statistical analysis}

Prior to statistical analysis, percent data were always transformed according to the algorithm arc $\sin V x$. To compare effectiveness of Varroa control and initial rates of mite fall for T and TCS, the Student $t$-test was applied. As effectiveness of both T and TCS was not significantly influenced by location, data relative to each product composition were pooled and submitted to 1way analysis of variance.

The effect of time and temperature on the rate of mite fall was investigated using the re- gression method. Temperature was expressed as the average number of degrees above zero in the time interval between 2 successive substitutions of inserts. The regression method was also used to verify: a), the influence of colony strength or dose of $T$ on the PE; b), the effect of outdoor temperature on bee mortality.

The difference among bee mortalities recorded in treated and untreated hives was tested with analysis of variance, replication being days following treatment. To evaluate bee mortality in the days preceding and following treatment the analysis of variance was also used; in that instance, replications consisted of the 4 combinations of product composition and location.

\section{RESULTS}

\section{Testing year 1987}

The number of mites collected after each application of $\mathrm{T}$ is reported in table $\mathrm{I}$; the number of mites surviving treatment and the percent effectiveness (PE) is also indicated. The mite response-curve checked in the $48 \mathrm{~h}$ following the first application is shown in figure 1 . The rate of mite fall relative to the first $3 \mathrm{~h}$ was significantly $(P=$ 0.05 ) higher than all rates successively recorded. Mite fall after the last treatment was also significantly affected by time $(r=$ $\left.-0.514^{*}\right)$ and temperature $\left(r=0.551^{*}\right)$ to give the response surface of figure 2. The effect of colony strength-dose of $T$ on PE is shown in figure 3 .

\section{Testing year 1988}

Table II shows data on mite mortality following each application of T and TCS, the number of surviving mites, and the effectiveness of control in each hive in the trial. The average PE was not significantly increased by the addition of confectioner's sugar. 
Table I. Number of fallen and surviving Varroa mites and percentage of effectiveness achieved with thymol treatment (testing year 1987).

\begin{tabular}{|c|c|c|c|c|c|c|c|c|}
\hline \multirow[t]{2}{*}{ Hive } & Fallen & mites & per & treatment & \multirow[t]{2}{*}{ Total } & \multirow[t]{2}{*}{ Surviving } & \multirow{2}{*}{$\begin{array}{c}\text { Grand } \\
\text { total }\end{array}$} & \multirow[t]{2}{*}{$\% E f f$} \\
\hline & $1 s t$ & 2nd & $3 r d$ & 4 th & & & & \\
\hline 1 & 695 & 787 & 387 & 247 & 2116 & 4 & 2120 & 99.81 \\
\hline 2 & 600 & 743 & 621 & 465 & ' 2429 & 10 & 2439 & 99.59 \\
\hline 3 & 237 & 465 & 304 & 355 & 1361 & 29 & 1390 & 97.91 \\
\hline 4 & 1805 & 777 & 365 & 140 & 3087 & 10 & 3097 & 99.68 \\
\hline 5 & 550 & 682 & 328 & 196 & 1756 & 7 & 1763 & 99.60 \\
\hline 6 & 2001 & 982 & 203 & 64 & 3250 & 12 & 3262 & 99.63 \\
\hline 7 & 556 & 468 & 346 & 164 & 1534 & 7 & 1541 & 99.55 \\
\hline 8 & 314 & 275 & 373 & 631 & 1593 & 84 & 1677 & 94.99 \\
\hline 9 & 711 & 256 & 132 & 110 & 1209 & 8 & 1217 & 99.34 \\
\hline 10 & 332 & 216 & 221 & 159 & 928 & 7 & 935 & 99.25 \\
\hline
\end{tabular}

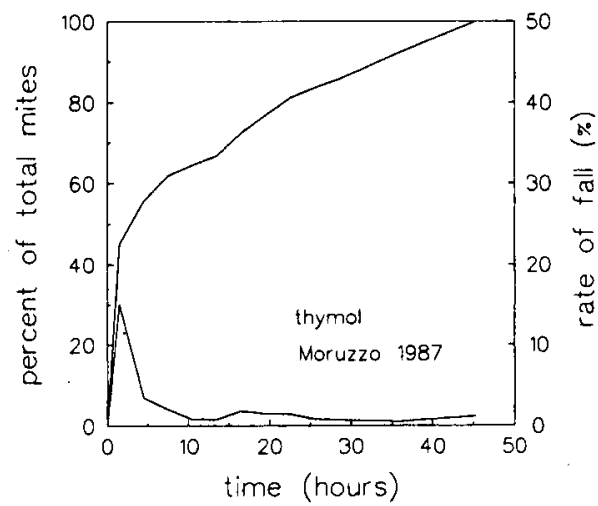

Fig 1. Cumulative percentage of fallen mites and rate of mite fall against time (first treatment).

In respect to the previous year a significant $(P=0.05)$ reduction was noted in the average $P E$ of $T$, due to the equalised doses of the product; actually, PE was significantly affected by colony strength, and that also occurred when confectioner's sugar was added (fig 4).

The rate of mite fall relative to the first application is shown in figure 5 . Large dif-

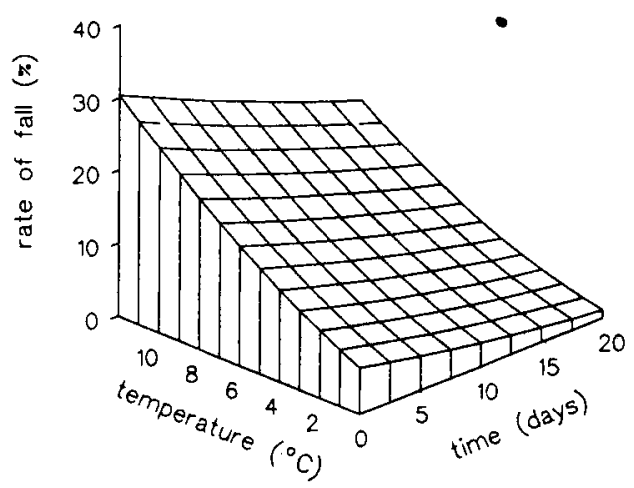

Fig 2. Combined effect of temperature and time on mite fall (percent on remaining ones) (testing year 1987).

ferences were noted in the trend when confectioner's sugar was present; in particular, a much more pronounced peak in mite fall was observed within the very first $\mathrm{h}$ following treatment. The graphs relative to the 2 locations closely resembled each other and a remarkable consistency in the mode of action was also found when comparing $T$ treatments carried out in 2 differ- 


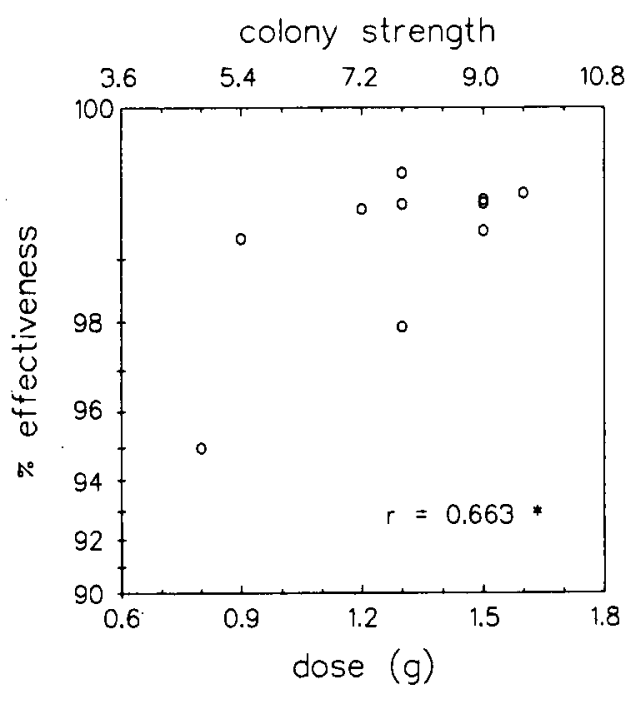

Fig 3. Effect of dose-colony strength on percent effectiveness achieved by treating honeybee colonies with thymol (testing year 1987).

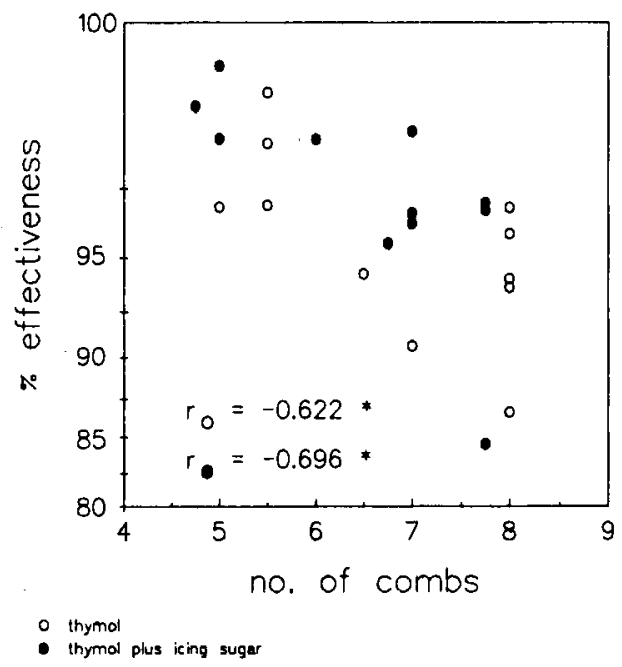

Fig 4. Effect of colony strength (No of combs occupied by bees) on percent effectiveness at constant doses of active ingredient (testing year 1988). O thymol; thymol plus confectioner's sugar.

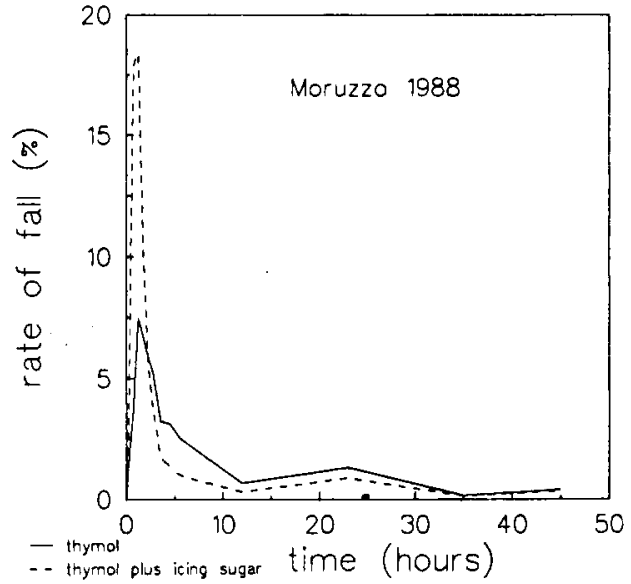

Fig 5. Rate of mite fall against time as affected by product composition. - thymol; ... thymol plus confectioner's sugar.

ent years (figs 1,5 ). If one group is excepted, namely that sited in Moruzzo and treated with $T$, the rate of the mite fall in the first $3 \mathrm{~h}$ was always significantly $(P=0.05)$ higher than every rate successively recorded (in the T-group at Moruzzo the only rate which did not statistically differ was inherent to the second 3-h period).

Bee mortality was generally affected by treatment; as shown in table III only the T. group of hives sited at Udine showed a mean mortality similar to the control. The influence of the product composition varied in the 2 locations: while at Udine TCS caused a significantly ( $P=0.05$ ) higher mortality than $T$, at Moruzzo no statistical difference was noted between the two. As far as $T$ treatment is concerned, the remarkable effect of location could tentatively be explained in terms of higher mortality at lower outdoor temperatures (fig 6). After the fourth application of both T and TCS, bee mortality soon declined to levels comparable to those recorded before treatment (table III). 
Table II. Number of fallen and surviving Varroa mites and percentage of effectiveness achieved by treating honeybee colonies with thymol and thymol plus confectioner's sugar (testing year 1988).

\begin{tabular}{|c|c|c|c|c|c|c|c|c|c|c|}
\hline \multirow{2}{*}{$\begin{array}{l}\text { Product } \\
\text { Compositior }\end{array}$} & \multirow{2}{*}{$\begin{array}{l}\text { Location } \\
n\end{array}$} & \multirow{2}{*}{ Hive } & \multirow{2}{*}{$\frac{\text { Fallon }}{1 s t}$} & \multirow{2}{*}{$\begin{array}{l}\text { mites } \\
\text { 2nd }\end{array}$} & \multirow{2}{*}{$\frac{p e r}{3 r d}$} & \multirow{2}{*}{$\frac{\text { treatment }}{4 \text { th }}$} & \multirow[t]{2}{*}{ Total } & \multirow[t]{2}{*}{ Surviving } & \multirow{2}{*}{$\begin{array}{c}\text { Grand } \\
\text { total }\end{array}$} & \multirow[t]{2}{*}{$\%$ Eff } \\
\hline & & & & & & & & & & \\
\hline \multirow[t]{2}{*}{ Thymol } & Moruzzo & $\begin{array}{l}1 \\
2 \\
3 \\
4\end{array}$ & $\begin{array}{r}793 \\
1796 \\
1243 \\
1256\end{array}$ & $\begin{array}{l}426 \\
594 \\
525 \\
331\end{array}$ & $\begin{array}{r}221 \\
171 \\
212 \\
95\end{array}$ & $\begin{array}{r}231 \\
115 \\
297 \\
92\end{array}$ & $\begin{array}{l}1671 \\
2676 \\
2277 \\
1774\end{array}$ & $\begin{array}{r}52 \\
12 \\
137 \\
24\end{array}$ & $\begin{array}{l}1723 \\
2688 \\
2414 \\
1798\end{array}$ & $\begin{array}{l}96.98 \\
99.55 \\
94.32 \\
98.67\end{array}$ \\
\hline & Udine & $\begin{array}{c}5 \\
6 \\
7 \\
8 \\
9 \\
10 \\
11\end{array}$ & $\begin{array}{l}367 \\
306 \\
172 \\
574 \\
370 \\
234 \\
668\end{array}$ & $\begin{array}{l}682 \\
453 \\
371 \\
452 \\
610 \\
282 \\
761\end{array}$ & $\begin{array}{l}354 \\
438 \\
268 \\
215 \\
549 \\
258 \\
254\end{array}$ & $\begin{array}{l}194 \\
543 \\
273 \\
135 \\
991 \\
306 \\
268\end{array}$ & $\begin{array}{l}1597 \\
1740 \\
1084 \\
1376 \\
2520 \\
1080 \\
1951\end{array}$ & $\begin{array}{r}67 \\
117 \\
68 \\
44 \\
388 \\
111 \\
62\end{array}$ & $\begin{array}{l}1664 \\
1854 \\
1152 \\
1420 \\
2908 \\
1191 \\
2013\end{array}$ & $\begin{array}{l}95.97 \\
93.70 \\
94.10 \\
96.90 \\
86.66 \\
90.68 \\
96.92\end{array}$ \\
\hline \multirow[t]{2}{*}{$\begin{array}{l}\text { Thymol + } \\
\text { confectione } \\
\text { sugar }\end{array}$} & $\begin{array}{l}\text { Moruzzo } \\
\text { r's }\end{array}$ & $\begin{array}{l}12 \\
13 \\
14 \\
15 \\
16\end{array}$ & $\begin{array}{r}476 \\
768 \\
717 \\
1706 \\
2714\end{array}$ & $\begin{array}{r}277 \\
669 \\
585 \\
452 \\
90\end{array}$ & $\begin{array}{r}186 \\
228 \\
350 \\
150 \\
37\end{array}$ & $\begin{array}{r}376 \\
281 \\
412 \\
175 \\
49\end{array}$ & $\begin{array}{l}1315 \\
1946 \\
2064 \\
2483 \\
2890\end{array}$ & $\begin{array}{r}240 \\
24 \\
25 \\
16 \\
5\end{array}$ & $\begin{array}{l}1555 \\
1970 \\
2090 \\
2499 \\
2895\end{array}$ & $\begin{array}{l}84.57 \\
98.78 \\
98.76 \\
99.36 \\
99.83\end{array}$ \\
\hline & Udine & $\begin{array}{l}17 \\
18 \\
19 \\
20 \\
21 \\
22\end{array}$ & $\begin{array}{c}2105 \\
1985 \\
553 \\
724 \\
474 \\
393\end{array}$ & $\begin{array}{l}332 \\
431 \\
628 \\
773 \\
543 \\
342\end{array}$ & $\begin{array}{l}134 \\
189 \\
265 \\
276 \\
358 \\
167\end{array}$ & $\begin{array}{l}179 \\
199 \\
212 \\
234 \\
330 \\
187\end{array}$ & $\begin{array}{l}2750 \\
2804 \\
1658 \\
2007 \\
1705 \\
1089\end{array}$ & $\begin{array}{l}30 \\
92 \\
50 \\
76 \\
58 \\
50\end{array}$ & $\begin{array}{l}2780 \\
2896 \\
1708 \\
2083 \\
1763 \\
1139\end{array}$ & $\begin{array}{l}98.92 \\
96.82 \\
97.07 \\
96.35 \\
96.71 \\
95.61\end{array}$ \\
\hline
\end{tabular}

\section{DISCUSSION}

Previous work on reinfestation rates of varroatosis as well as on rates of mite mortality throughout the year demonstrated that in temperate regions autumn treatment on brood free colonies ensured the best results against the disease (Romaniuk and Duk, 1983; Schulz, 1984; Marchetti et al, 1988). The greater effectiveness of acaricide products in this period was found to be associated with lower or non-existent amounts of residues in honey (Taccheo Barbina et al, 1988; 1989a,b). To minimize the risk of temperature drops during the treatment period, it was reduced to $8 \mathrm{~d}$, shortening the time interval between 2 consecutive applications.

Treatment with powdered $T$ according to this pattern of control caused a dramatic reduction in the mite population. In 1987 PE was higher than $99 \%$ in most hives; the lowest value (ie $94.99 \%$ ), achieved in hive No 8 , was due to the presence of some brood throughout the treatment period. The coefficient of variation was as low as $3.74 \%$, indicating a remarkable consistency in results. In 1988 values of PE were generally lower; in particular, the average PE for $\mathrm{T}$ treatment was significantly $(P=$ $0.05)$ reduced in respect to that of the previous year (94.95 vs $98.94 \%)$. The de- 
Table III. Average bee mortality, per hive and per day, as affected by product composition, location and time after the first treatment.

Mean mortality

$\begin{array}{lcc}\text { T Moruzzo } & 65.91 & \mathrm{a} \\ \text { TCS Moruzzo } & 53.33 & \mathrm{ab} \\ \text { TCS Udine } & 41.77 & \mathrm{~b} \\ \text { T Udine } & 19.57 & \mathrm{c} \\ \text { Control } & 10.02 & \mathrm{c} \\ & & \\ \text { Days after 1st treatment } & & \mathrm{a} \\ 3 & 61.6 & \mathrm{a} \\ 5 & 60.5 & \mathrm{a} \\ 1 & 57.5 & \mathrm{ab} \\ 8 & 46.3 & \mathrm{ab} \\ 4 & 45.3 & \mathrm{ab} \\ 7 & 43.9 & \mathrm{bc} \\ 2 & 27.9 & \mathrm{bc} \\ 6 & 24.6 & \mathrm{bc} \\ 9 & 21.8 & \mathrm{c} \\ 0 \text { (") }^{*} & 15.0 & \mathrm{c} \\ -1 & 12.8 & \mathrm{c} \\ -2 & 10.9 & \mathrm{c} \\ -4 & 8.0 & \mathrm{c} \\ 10 & 7.8 & \mathrm{c} \\ -5 & 7.5 & \mathrm{c} \\ -3 & 5.8 & \end{array}$

(\$)

$a b$

b

c

a (\$)

a

$a b$

$a b$

$a b$

bc

bc

bc

c

C

C

c

c

c

c

)

(\$)

$\left({ }^{*}\right)$ : Day of first treatment; (\$): Duncan's multiple range test; means with a letter in common are not statistically different at $P=0.05$.

crease could not be interpreted in terms of factors other than the different manner of $T$ administration to the colony; actually, it should be remembered that in $1987 \mathrm{~T}$ was given at a rate of $0.5 \mathrm{~g}$ per 3000 bees (that is $0.5 \mathrm{~g}$ per comb completely covered with a monolayer of bees) whereas in the following year all colonies received the same amount of $T$ irrespective of colony strength. Under these conditions, PE was negatively correlated to colony strength and consequently the coefficient of variation increased to 6.32 and $6.82 \%$ for $T$ and TCS respectively. Results achieved in this trial indicate that PE can be significantly af- fected by $T$ dose and that satisfactory control of varroatosis can be achieved even in strong colonies provided that the $T$ dose is adjusted to higher levels using the abovementioned relationship. The effect of an increasingly higher number of bees observed in this experiment is exactly the oppositive of that hypothesized by Mikitiuk (1983) who found a major sublimation in strong colonies compared to weak colonies, possibly because of the greater airflow generated by fan bees.

The addition of confectioner's sugar to $T$ caused a non significant increase in PE; it should be remembered, however, that the 


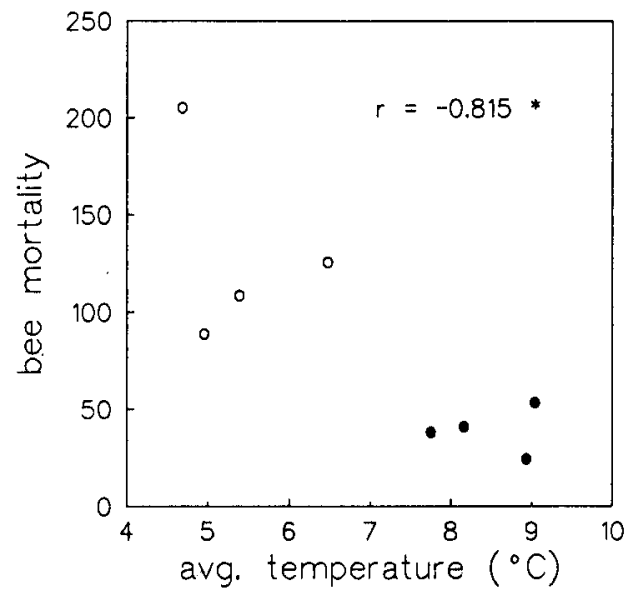

Fig 6. Correlation between bee mortality (No of bees/hive found dead after each application of thymol) and average temperature (the 2 locations are indicated by different markers) (testing year 1988).

average PE for TCS (96.62\%) approached that recorded for $T$ in 1987 from which no statistical difference was noted. Furthermore, the rate of mite fall in the very first $3-h$ period following treatment was remarkably higher when using TCS (figs 1, 5).

The mite response-curve to T and TCS closely resembled those of active ingredients produced only via chemical synthesis such as Coumaphos and Amitraz (Marchetti and Barbattini, 1984; Marchetti and D'Agaro, 1986). Therefore, the changes in formulation are not only reflected in a consistently higher effectiveness but also in a great enhancement in activity in a very short period of time (Marchetti and Barbattini, 1984).

Bee mortality was transiently affected by treatment; soon after the administration of $T$ and TCS a perceivable bustle ran through the colonies. In 1987 bees were observed escaping in a few cases, so the following year a sheet of paper was fixed over the hive entrance prior to each application of $T$ and TCS. Next morning the bees themselves removed the obstacle and began their normal activity again. Interestingly enough, it was not necessarily the strongest colonies that showed the major bustle in 1987; also in the following year the magnitude of bustle was unrelated to colony strength and seemed peculiar to each colony. As stated in Marchetti et al (1987), modified Gary's traps can often lead to the underestimation of bee losses; it may be recalled that mortality caused by Coumaphos treatments was at least twice as great as that of T. A more precise evaluation of bee mortality will be the subject of later trials. Both years all colonies survived treatment and were able to produce honey the following season. By means of organoleptic assay, honey extracted from treated and untreated colonies sited in the same area were found to be indistinguishable.

It should be remembered that $T$ was used for experimental purposes only; so far in all European countries the product has not been particularly recommended for apicultural use.

\section{ACKNOWLEDGMENTS}

We thank Dr S Marchetti for assistance during statistical analysis and $\mathrm{Dr} \mathrm{N}$ Milani for providing the meteorological data in Udine. This research was supported by the Ministerio dell'Università $\theta$ della Ricerca Scientifica e Tecnologica research project, "Control and improvement of apiarian products" (coordinator: Prof R Prota, University of Sassari).

Résumé - Efficacité de la lutte contre la varroatose à l'aide de thymol en poudre. Des traitements d'automne à base de thymol en poudre ont été effectués à Udine et Moruzzo (Nord-Est de l'Italie) en 
1987 et 1988, afin de disposer d'une méthode de lutte conséquente et dépourvue d'effets non intentionnels néfastes, tels que les résidus toxiques dans les produits de la ruche. Quatre applications identiques du produit ont été faites à 2 j d'intervalle dans des colonies ayant peu ou pas de couvain. En 1987, une dose de $0,5 \mathrm{~g}$ de thymol a été donnée à chaque rayon entièrement couvert d'abeilles $(0,5 \mathrm{~g}$ pour 3000 abeilles); en 1988, $1 \mathrm{~g}$ de thymol a été donné à chaque colonie indépendamment de sa force et dans la moitié des ruches, un mélange de thymol et de sucre glace $(1: 1 \mathrm{w} / \mathrm{w})$ a été appliqué à la place du thymol seul.

Le traitement avec le thymol en poudre a provoqué une réduction drastique de la population d'acariens. En 1987, l'efficacité a été supérieure à $99 \%$ dans la plupart des ruches (tableau I) avec une moyenne de $98,94 \%$. En 1988 on a observé une baisse du pourcentage de l'efficacité du thymol en raison de la quantité égale de produit distribuée (indépendamment de la force de la colonie) (tableau II). On a pu montrer ainsi que la force de la colonie influençait significativement le pourcentage d'efficacité (fig 3 et 4). La température (fig 2) affecte de façon significative la mortalité des acariens. II en est de même pour le temps écoulé : la courbe de mortalité montre un taux de mortalité plus élevé durant les 3 premières $h$ que pendant les $h$ suivantes (fig 1). L'adjonction au thymol de sucre glace a provoqué un accroissement remarquable du taux de mortalité dans les 3 premières $h$ suivant le traitement (fig 5) mais pas un accroissement significatif du pourcentage d'efficacité. A l'aide de trappes de Gary posées sur des colonies traitées et des colonies non traitées, on a montré que le traitement augmentait passagèrement la mortalité des abeilles (tableau III). Dans un rucher où les températures extérieures avaient été plus basses, la mortalité a augmenté (fig 6). Pour éviter que les abeilles ne quittent la ruche (ce qui s'est parfois produit après les traitements au thymol), une feuille de papier était fixée sur l'entrée de la ruche avant chaque traitement. Le lendemain matin les abeilles otaient ellesmêmes l'obstacle et reprenaient leur activité normale. Toutes les colonies ont survécu aux traitements des 2 années et ont pu produire du miel la saison suivante. Bien que le thymol soit considéré comme non dangereux pour l'homme, il n'a jusqu'à présent encore jamais été autorisé comme moyen thérapeutique pour les abeilles.

\section{Apis mellifera / varroatose / lutte chimi- que / thymol}

\section{Zusammenfassung - Wirksame Varro- atose-Kontrolle durch Thymol-Puder.} Um eine konsequente Varroakontrolle ohne schädliche Nebenwirkungen wie toxische Rückstände in den Produkten des Bienenvolkes zu erzielen, wurden während der Jahre 1987 und 1988 in Udine und Moruzzo (Nordostitalien) Herbstbehandlungen mit gepudertem Thymol durchgeführt. Die Behandlung bestand aus vier gleichartigen Anwendungen in Völkern mit wenig oder keiner Brut in zwei Tagen Abstand. Im Jahre 1987 wurde für jede vollständig mit einer einfachen Bienenschicht bedeckte Wabe eine Dose von $0.5 \mathrm{~g}$ Thymol gegeben ( $0.5 \mathrm{~g}$ pro 3.000 Bienen). 1988 wurde jedem Volk unabhängig von seiner Stärke ein Gramm Thymol verabreicht; bei der Hälfte der Völker wurde eine Mischung von Thymol und Puderzucker (1:1 w/w) anstelle von Thymol allein gegeben.

Ergebnisse. Die Behandlung mit gepudertem Thymol verursachte einen dramatischen Rückgang der Milbenpopulation. 1987 war die prozentuelle Wirksamkeit bei den meisten Völkern höher als $99 \%$ (Tabelle I) mit einem Mittelwert von $98.94 \%$. 1988 wurde auf Grund der gleichen Wirkstoffmenge (unabhängig von der Volksstär- 
ke) ein Rückgang der prozentellen Wirksamkeit von Thymol beobachtet (Tabelle II); es konnte gezeigt werden, daß die Volksstärke die prozentuelle Wirksamkeit deutlich beeinflußt (Fig 3 und 4). Der Milbenabfall wurde signifikant durch Zeit und Temperatur beeinflußt (Fig 2). Die Abfallkurve der Milben zeigt für die ersten drei Stunden eine höhere Abfallrate als in allen folgenden Perioden (Fig 1). Die Zugabe von Puderzucker zum Thymol verursachte in den ersten drei Stunden nach Behandlung einen beachtlichen Anstieg des Abfalls (Fig 5), aber keinen signifikanten Anstieg in der Gesamtwirksamkeit.

Mittels Gary's Bienenfalle an behandelten und unbehandelten Völkern konnte festgestellt werden, daß die Bienensterblichkeit vorübergehend anstieg (Tabelle III). Auf einem Bienenstand mit niedrigerer Außentemperatur war die Bienensterblichkeit höher (Fig 6). Um das Ausfliegen von Bienen (wie es gelegentlich nach der Thymolbehandlung $\mathrm{zu}$ beobachten war) $\mathrm{zu}$ verhindern, wurde vor jeder Behandlung ein Blatt Papier über das Flugloch gespannt. Am nächsten Morgen entfernten die Bienen das Papier und begannen ihre normale Flugtätigkeit. In beiden Jahren überlebten alle Völker die Behandlungen und sie konnten im nächsten Jahr Honigernten einbringen.

Obwohi Thymol für den Menschen als relative undenklich gilt, wurde es bisher noch nirgends für den therapeutischen Einsatz im Bienenvolk zugelassen.

\section{Apis mellifera / Varroatose / chemische Kontrolle / Thymol}

\section{REFERENCES}

Colin ME, Ducos de Lahitte J, Larribau E, Boué $T$ (1989) Activité des huiles essentielles de Labiées sur Ascosphaera apis et traitement d'un rucher. Apidologie 20 (3), 221-228
Cooperativa Farmaceutica Milano (1980) Medicamenta 4th edn

Eble H, Weide W (1961) Control of Pericytis apis Maassen in the laboratory and in practice. Wiss $Z$ Univ Halle Math Nat 10 (1), 8386 (in German) (Apic Abstr 1964, 15, p 72)

Fenaroli $G$ (1963) Le sostanze aromatiche. In: Sostanze Aromatiche Naturali. Hoepli, Milan, vol I

Galoppini C (1985) Voce "Timolo". In: Enciclopedia Agraria Italiana. REDA, vol XII

Gary NE (1960) A trap to quantitatively recover dead and abnormal honey bees from the hive. J Econ Entomol 53 (5), 782-785

Grobov OF, Mikitiouk VV, Gousseva LN (1981) Le thymol, substance à spectre large d'activité. Apiacta 16, 64-65, 76

Hoppe H, Ritter W (1989) Comparative examinations for the control of varroatosis by means of ethereal oils. In: Present Status of Varroatosis in Europe and Progress in the Varroa Mite Control. Proc Meet EC Experts' Group, Udine 1988 (Cavalloro E, ed) Commission of European Communities, Luxembourg, 301-306

Kambourov G, Kirillow N, Pyrvanov $P$, Kolev $K$ (1983) Les produits chimiques et végétaux dans la lutte contre Varroa jacobsoni. 29th Int Congress of Apiculture, Budapest 1983, Apimondia, Bucharest, p 243

Kotecki $R$ (1976) Investigations on the use of thymol in the treatment of acarine disease of honeybees during overwintering. Tierarztl Umsch 31 (9), 398-401 (in German) (Apic Abstr 1980, 31, p 106)

Leporati M, Giordani G (1982) Controllo in campo dell'acariosi delle api con mentolo. Quaderni di documentazione a cura della Federazione Apicoltori Italiani, Elengraf, Rome

Marchetti S (1985) II "Metodo dei sesti" per la valutazione numerica degli adulti in famiglie di Apis mellifera L. Apicoltura 1, 41-61

Marchetti S, Barbattini R (1984) Comparative effectiveness of treatments used to control Varroa jacobsoni Oud. Apidologie 15 (4), 363377

Marchetti S, D'Agaro M (1986) Perizin liquid, a systemic agent for the chemical control of varroatosis. Apicoltura 2, 67-76 
Marchetti S, Chiesa F, D'Agaro M (1987) Bee mortality following treatment with Perizin in colonies of Apis mellifera carnica $\times$ A m ligustica. Apicoltura 3, 157-172

Marchetti S, Frilli F, D'Agaro M (1988) Reinfestation rates of varroatosis after treatments in brood-free colonies. In: European Research on Varroatosis Control. Proc Meet EC EXperts' Group, Bad Homburg 1986 (Cavalloro R, ed) AA Balkema, Rotterdam, 145-156

Mautz D (1982) Untersuchungen zur Bienengefährlichkeit von Thymol. Apidologie 13 (1), 103-104

Mikityuk VV (1983) Efficacy of thymol against Varroa disease. Veterinariya 1, 43-44 (in Russian) (Apic Abstr 1983, 34, p 265)

Mikityuk VV, Grobov OF, Chigareva OI (1979) Trials of chemicals for controlling Varroa jacobsoni infestations of bees. Tr Vses Inst Exsf Vet 50, 120-125 (in Russian) (Apic Abstr 1982, 33, p 123)

Mladan V, Erski-Biljic $M$, Jakic $D$, Simic $M$ (1985) Use of some preparations (Folbex VA, thymol Apiakaridin, Varikol, Varitan and phenotiazine) in the control of Varroa. I. Vet Glas 39 (4/5), 489-496 (in Serbo-croat) (Apic Abstr, 1986, 37, pp 319-320)

Reynolds SEF (ed) (1982) Martindale-The Extra Pharmacopea. The Pharmaceutical Press, London

Romaniuk K, Duk S (1983) Seasonal dynamics of the development of Varroa jacobsoni in untreated honeybee colonies. Med Vet 39 (12), 725-727 (in Polish); (Apic Abstr, 1985, p 57)

Saleh MA (1986) A desert plant from Egypt, Anabasis setifera: an efficient natural factory of carvacrol and thymol. J Agric Food Chem 34, 192-194

Schulz AE (1984) Reproduction and population dynamics of the parasitic mite Varroa jacobsoni Oud and its dependence of the brood cycle of its host Apis mellifera L (Part I). Apidologie 15 (4), 401-420

Sidorov NG, Stolbov NM, Platukhina NI (1977) The effect of volatile oils of higher plants on the agent of varroatosis of bees. Veterinariya 7, 65-68 (in Russian) (Rev Appl Entomol, Ser A 1978, 66, p 62)

Smirnov AM (1978) Progrès actuels de la science en Union Soviétique dans l'étude de l'éthiologie, de la pathogénie, de l'épizootologie, du diagnostic et de la lutte contre la varroase des abeilles. Apiacta 13, 149-162

Taccheo Barbina M, De Paoli M, Marchetti S, D'Agaro M (1988) Bromopropylate decay and residues in honey samples. In: European $\mathrm{Re}$ search on Varroatosis Control. Proc Meet EC Expert's Group, Bad Homburg 1986 (Cavalloro R, ed) AA Balkema, Rotterdam, 131-143

Taccheo Barbina M, De Paoli M, Chiesa F, D'Agaro M, Pecol U (1989a) Coumaphos decay and residues in honey samples. In: Present Status of Varroatosis in Europe and Progress in the Varroa Mite Control. Proc Meet EC Experts' Group, Udine 1988 (Cavalloro R, ed) Commission of European Communities, Luxembourg, 379-386

Taccheo Barbina M, De Paoli M, Barbattini R, Chiesa F, Milani N, D'Agaro M (1989b) Residues in hive products of chemicals used to control Varroa jacobsoni Oud. In: Present Status of Varroatosis in Europe and Progress in the Varroa Mite Control. Proc Meet EC Experts' Group, Udine 1988 (Cavalloro R, ed) Commission of European Communities, Luxembourg, 369-377

Vecchi MA, Giordani G (1968) Chemotherapy of acarine disease. 1. Laboratory test. J Invertebr Pathol 10 (2), 390-416

Wilson WT, Moffett JO, Cox RL, Maki DL, Richardson $H$, Rivera $R$ (1988) Menthol treatment for Acarapis woodi control in Apis mellifera and the resulting residues in honey. In: Africanized Honey Bees and Bee Mites (Needham GR, Page RE Jr, Delfinado-Baker $M$, Bowman CE, eds) Ellis Horwood Ltd, Chichester, 535-540

Windholz M (ed) (1983) The Merck Index. An Encyclopedia of Chemicals, Drugs, and Biologicals. Merck and Co Inc, Rahway 